\title{
Genre analysis of the "About Us" Genre analysis sections of Asian Association of Open Universities websites
}

\author{
Louise S. Villanueva, Mary Aizel C. Dolom and Jennifer S. Belen \\ Office of the Vice Chancellor for Academic Affairs, \\ University of the Philippines Open University, Laguna, Philippines
}

\begin{abstract}
Purpose - This paper is a corpus-driven study of written electronic texts, particularly the "About Us" sections in the university websites of 41 members of the Asian Association of Open Universities (AAOU). This inquiry is important because it will provide an insight as to how AAOU members describe and portray themselves in the World Wide Web, a platform which is highly utilized in the field of distance education. This will also lead to the understanding of conventional knowledge among AAOU members during the period of study. The paper aims to discuss these issues.

Design/methodology/approach - Guided by Swales' (1990) seminal work on genre analysis, the researchers conducted a three-part genre analysis which involved identification and analysis of moves, keywords, and concordance lines.

Findings - Results of the keyword analysis were conducted using the AntConc application. Anthony (2017) found that the top 100 keywords with positive keyness exemplified inherent characteristics of open and distance learning institutions as well as characteristics common to higher education institutions and their thrusts. The analysis also found that the use of adjectives and verbs with positive denotations is common in the "About Us" sections. Concordance for several keywords related to the overarching theme of the AAOU 2017 Conference then revealed that the AAOU members are active in the discourse about accessibility, assessment, and quality, while there is not much discourse on openness, inclusivity, and justice. Meanwhile, subscribing to equality and equity could still be a point of discussion among the AAOU members as the concordance analysis revealed more discourse on equality than equity as a goal and principle. Overall, results of the genre analysis resonated with previous studies of the academic genre as the "About Us" sections are promotional in both authoritarian and inclusive ways.

Originality/value - The inquiry will provide the members of the AAOU with an overview of their common communicative purposes, overused or underused keywords, and their usage of these words which they may opt to work on in the future.
\end{abstract}

Keywords Academic web genre, Corpus-based study, Genre analysis, Keyword analysis,

Open and distance learning genre

Paper type Research paper

\section{Introduction}

Genre analysis involves the study of language and its usage and application in different settings (Bhatia, 1997). As a method that uncovers structural patterns of texts, genre analysis led to a plethora of studies that provided an understanding of genre across academic disciplines. Scholars have also come up with different approaches to genre analysis and applied these to written and spoken texts (Pho, 2013). However, the emergence of the World Wide Web offers new avenues to apply genre analysis to electronic texts.

C Louise S. Villanueva, Mary Aizel C. Dolom and Jennifer S. Belen. Published in the Asian Association of Open Universities Journal. Published by Emerald Publishing Limited. This article is published under the Creative Commons Attribution (CC BY 4.0) licence. Anyone may reproduce, distribute, translate and create derivative works of this article (for both commercial and non-commercial purposes), subject to full attribution to the original publication and authors. The full terms of this licence may be seen at http://creativecommons.org/licences/by/4.0/legalcode

The authors wish to thank the University of the Philippines Open University for the research grant that enabled the conduct of this study.
Received 11 January 2018 Revised 12 February 2018 Accepted 12 February 2018 
AAOUJ

13,1

This provides a new area that will allow researchers to make sense of conventional knowledge as presented in the World Wide Web.

In the context of education, scholars have been dissecting parts of university websites. Tomarkova (2015) studied the websites of American, British, and Czech universities to determine similarities and differences in terms of multimodal features. It was found that the universities differed in their representation, and these could be attributed to their social and cultural contexts. Meanwhile, some scholars took a critical approach in studying university websites. One example is Zhang and O'Halloran's (2013) analysis of the National University of Singapore's (NUS) website and strategies which positioned the university as a global player rather than a national institution and found that in the past 14 years, NUS's website shifted from an information-based to a consumer-based approach. These findings also resonated with a study conducted by Jessee (2009) which focused on student profiles published in university websites. These profiles were found to be promotional in function, but were also anchored in the academic and research thrusts of the universities. Given these examples, it can be said that scholars have recognized university websites as a means of promotion. While this assumption has been founded, Caiazzo (2009, as cited in Yang, 2013) still recognized university websites as excellent study texts for corpus linguistics. Accordingly, this will permit an in-depth look into universities' construction of social realities and the meanings that they attached in varying contexts.

The current study is an attempt to apply corpus linguistics in written electronic texts, particularly the "About Us" sections of Asian Association of Open Universities (AAOU) members' websites (Asian Association of Open Universities, n.d.a,b). This inquiry is important because it will provide an insight as to how AAOU members describe and portray themselves in the World Wide Web, a platform which is highly utilized in the field of distance education. This will also lead to the understanding of conventional knowledge among AAOU members during the period of study. Moreover, as genre is deemed as a dynamic construct (Bhatia, 1997), the inquiry will provide the members of the AAOU with an overview of their common communicative purposes, overused or underused keywords, and their usage of these words which they may opt to work on in the future. With these, the researchers asked the following questions:

$R Q 1$. What are the rhetorical moves of the "About Us" sections of AAOU members' websites?

$R Q 2$. What are the overused and underused keywords utilized by AAOU members in their "About Us" sections?

RQ3. In what contexts do AAOU members used specific keywords in their "About Us" sections?

\section{Related Literature}

In describing the macrostructure of the "About Us" sections, the researchers used Swales' (1990) concept of rhetorical moves. Accordingly, rhetorical moves are discourse units that require researchers to segment parts of the texts based on their communicative purpose. In Swales' seminal work, these rhetorical moves permit those who are not part of the discourse community to understand and learn about the genre. One of the foremost move analyses conducted on websites was done by Askehave and Nielsen (2005) on a European industrial company website. Accordingly, the website employed the following rhetorical moves to achieve its communicative purpose: attracting attention; greeting; identifying sender; indicating content structure; detailing (selected) content; establishing credentials; establishing contacts; establishing a discourse community; and promoting an external organization. Guided by Askehave and Nielsen (2005), scholars have also followed through 
with genre analysis of websites. Isa et al. (2016) used Askehave and Nielsen's (2005) rhetorical moves as benchmark in analyzing the websites of oils and gas companies worldwide. The same was done by Johari and Ali (2015) in their analysis of the websites of Malaysian small and medium enterprises (SMEs). The scholars found that while Malaysian SMEs had varying moves, the goal of these companies was still evident and that was to persuade customers to buy company products and/or avail company services. Sensitivity to audience's needs could also be observed as the websites of Malaysian SMEs maximized on Islamic contents.

In the context of education, move analysis has been employed in the study of academic outputs. It has been applied to research articles across different fields of study. Cross and Oppenheim (2006) analyzed the abstracts of protozoology studies, and managed to uncover a five-move pattern which included the following: situating the research within the scientific community; introducing the research through its features and/or objectives; describing the methodology; discussing results; and drawing conclusions and presenting recommendations. Scholars have also been interested in the similarities and differences of abstracts written by native and non-native English speakers (e.g. Li, 2011; Marefat and Mohammadzadeh, 2013; Niu, 2013; Talebzadeh et al., 2013; Benham and Golpour, 2014; Nasseri and Nematollahi, 2014; Al-Khasawneh, 2017). Aside from abstracts, move analysis has also been applied to application essays. Ding (2007) analyzed the moves used by medical and dental school applicants. Among these were "explaining the reason to pursue the proposed study; establishing credentials related to the fields of medicine/dentistry; discussing relevant life experience; stating future career goals; and describing personality." Samraj and Monk (2008) also used move analysis to compare the application essays of applicants to the Linguistics, Business Administration, and Electrical Engineering program of a state university.

In the study of academic websites, Yang (2013) conducted a move analysis in the "Why Choose Us?" section of websites of universities worldwide. The analysis yielded the following six moves used to promote universities to potential students: establishing a distinguished status; ensuring excellent teaching quality; presenting a leading role in research; offering attractive incentives; enjoying a friendly environment; and ending with suggestions. Meanwhile, Zhang (2017) dissected the "About Us" sections of five universities in China, and found that there were seven obligatory or optional moves exemplified by 11 different sub-sections. These were as follows: welcoming (e.g. president's message); establishing credentials (e.g. overview, history, facts \& figures, publications); describing administration (e.g. leadership); attracting attention (e.g. university logo, motto, song, video); offering extra services (e.g. facilities available, international student services); locating the service (e.g. visiting the campus); and soliciting response (e.g. contact us).

Aside from mapping out the moves in the electronic texts, genre analysis can also be approached through keyword analysis (Trible, 1999 as cited in Xiao and McEnery, 2005). Keyword analysis allows researchers to determine the words considered as "key" since these have unusual frequency in relation to a reference corpus (Scott, 1997 as cited in Gabrielatos and Marchi, 2012). According to Scott (2015), keyness may be positive or negative. Words with positive keyness appeared "more often than would be expected by chance in comparison with the reference corpus" while words with negative keyness occurred less. Keyword analysis has been at the core of research studies in literature. Scholars relied on keyness to dissect the works of prominent writers such as William Shakespeare (Culpeper, 2009), Jane Austen (Fischer-Starcke, 2009), and John Irving (Cermakova, 2015). Likewise, social scientists have also incorporated keyword analysis in the study of media and politics such as Barrett's (2007) comparison of articles about the war on terror published by newspapers in the USA, Great Britain, and Germany, Clark's (2011) study about the Iraq war based on the broadcasts of BBC and CBS, and 
AAOUJ

13,1

Charteris-Black's (2012) dissection of Tony Blair's speeches. Keyword analysis has also been helpful in understanding academic web genre. Yang (2013) generated the keyness of the "Why Choose Us?" sections of university websites through the use of Scott's (2008) Wordsmith tool. The analysis yielded more overused than underused keywords. The keywords were also consistent with the promotional nature of the genre that also portrayed the universities as both authoritarian and inclusive. The use of collective pronouns such as "we" and "our" were overused to personalize (Fairclough, 1993 as cited in Yang, 2013) the universities, and connect more to the readers. Similarly, adjectives in superlative forms were also overused to attract more students. Words that conveyed absence or contradiction such as "no," "but," or "not" were avoided.

While keyness renders a quantitative perspective of the electronic texts, concordance lines have also been of interest among scholars because they serve as indicators of the contexts where the words occurred (Kent University, n.d.). Concordances have been deemed helpful in the English language learning and vocabulary retention of non-native speakers (Jalilifar et al., 2014; Yilmaz and Soruc, 2015). Accordingly, concordances permit learners to make sense of English words easily. Aside from this, concordances also allow researchers to link words with the bigger context, a method forwarded by Weber (2001) in teaching law undergraduates how to write legal essays. Web genre has also benefitted from the use of concordances. Jimenez-Crespo (2011) analyzed American corporate websites geared for customers in Spain. Significant differences and impact were found in the use of Spanish words in original and localized legal sections.

Guided by the literature cited on move analysis, keyword analysis, and concordance or keyword-in-context analysis, the researchers proceeded with the three-part genre analysis.

\section{Methodology}

The researchers chose to study the "About Us" sections of AAOU members' websites in order to grasp how open universities in Asia present themselves. In line with this, the researchers referred to the AAOU website to get the list of their full and associate members (AAOU, n.d.a, b). All of these members were considered for the study. Exclusion was only applied in the following cases: the university website does not have an explicit "About Us" page; the university website is down during the duration of the data gathering; the university website belongs to the supra-system where the open university is a constituent; and the university website does not have a direct and complete English translation. In the course of the study, the researchers managed to dissect the "About Us" sections of 41 out of 63 full and associate members of AAOU (Table I).

After the selection of samples, the researchers proceeded to conduct the move analysis. It is important to note that while Swales defined what constitutes as rhetorical moves, he did not specify how move boundaries can be determined (Lewin et al., 2001, as cited in Nordquist, 2017). With these, the researchers relied on how each of the "About Us" section was divided. This came in the form of sub-sections that have individual hyperlinks. The researchers read each sub-section and noted how these were sequentially arranged in the "About Us" sections. There were many overlapping sub-sections and the researchers had a consensus as to which sub-section should be merged with another. Since the researchers ranked how these sub-sections were presented, the median was used to arrive with the final sequence of the sub-sections or in this case, the rhetorical moves. If a tie between two rhetorical moves was found, the researchers then looked at the mode then the mean of the sequences.

For the keyword analysis, the researchers manually collected the electronic texts through the use of an open-sourced scraper (Heaton, 2010) for Google Chrome. The contents were then compiled into a text file that was loaded to AntConc 3.5.0, an open-sourced text analysis software developed by Lawrence Anthony (2017) of Waseda University. In order to measure keyness in AntConc, the electronic texts were analyzed in relation to 
Type of membership University

Full

\author{
1. Al-Madinah International University, Malaysia \\ 2. Allama Iqbal University, Pakistan \\ 3. Asian e-University, Malaysia \\ 4. Beijing Open University, China \\ 5. Chongquing Radio and TV University, China \\ 6. Dr B.R. Ambedkar Open University, India \\ 7. Hanyang Cyber University, Korea \\ 8. Ho Chi Minh City Open University, Vietnam \\ 9. Indira Gandhi National Open University, India \\ 10. Institute of Distance and Open Learning, Gauhati University, India \\ 11. International Center for Academics, Nepal \\ 12. Karnataka State Open University, India \\ 13. Korea National Open University, Korea \\ 14. Krishna Kanta Handiqui State Open University \\ 15. National Open University, Taiwan \\ 16. Open University Malaysia, Malaysia \\ 17. Payame Noor University, Iran \\ 18. School of Open Learning, University of Delhi, India \\ 19. Shanghai Open University, China \\ 20. Singapore University of Social Sciences, Singapore \\ 21. Sukhothai Thammathirat Open University, Thailand \\ 22. Symbiosis Center for Distance Learning, India \\ 23. Tamilnadu Open University, India \\ 24. The Open University of China, China \\ 25. The Open University of Hong Kong, China \\ 26. The Open University of Japan, Japan \\ 27. The Open University of Kaohsiung, Taiwan \\ 28. The Virtual University of Pakistan, Pakistan \\ 29. Tianjin Open University, China \\ 30. UNITAR International University, Malaysia \\ 31. Universitas Terbuka, Indonesia \\ 32. University of the Philippines Open University, Philippines \\ 33. Wawasan Open University, Malaysia \\ 34. Yangon University of Distance Education, Myanmar \\ 35. Yunnan Open University, China \\ 38. Islamic Online University, Gambia \\ 39. Don Mariano Memorial State University (DMMSU) Open University, Philippines \\ 40. Northern Ireland Institute of Business and Technology British, UK \\ 41. Southeast Asian Ministers of Education Organization Regional Open \\ Learning Center (SEAMOLEC), Thailand
}

Associate $\quad 37$. Arab Open University, Kuwait

Table I. AAOU members' websites included in the samples

The British National Corpus (2007), one of the largest and most used reference corpora. Keyness comes in log-likelihood or chi-square statistics. In this study, the researchers used log-likelihood as it is deemed more reliable and more considerate of data that is not normally distributed (Xiao, n.d.). More than the log-likelihood scores which determine statistical significance, Gabrielatos and Marchi (2012) suggested for researchers to also consider effect size which is the percentage difference of the frequencies of electronic texts being studied and the reference corpus. Both log-likelihood and effect sizes were considered for the current study. The researchers did not employ a stop list. Instead, keyness for words was generated organically, and the researchers deliberated on the keywords that could be eliminated due to insignificance. These commonly included linking verbs, articles, prepositions, and conjunctions. 
AAOUJ 13,1

Table II.

Rhetorical moves employed by the AAOU members in their "About Us" sections
For the concordance analysis, the concordance function of AntConc (Anthony, 2017) was used to determine the location of words in the website and analyze how these were used. The analysis yielded a total of 7,300 words, when aggregated. From these 7,300 words, the researchers selected and agreed on which words would be the focus of the study. The researchers only selected those that were related to AAOU 2017 Conference's main theme, "Open University for Inclusive and Equitable Quality Education" and the following sub-themes: "Repositioning Open University in the Digital Era: Providing Sustainable Learning Pathways"; "Leadership in Open, Distance, and Online Learning University"; "Quality Assurance in Open University"; "Assessment and Accreditation of Learning in Open University"; and "Access and Justice in Open, Distance and Online Learning" (AAOU, 2017). This was done to ensure that the study was in line with what the AAOU deemed as important trends in the field of open and distance education. With regard to the context of the words, the researchers conducted a microanalysis of the sub-sections where the words appear. This was followed by paragraph and sentence microanalysis. The researchers relied on consensus in terms of merging and separating identified themes.

\section{Results and discussion}

\subsection{Move analysis}

AAOU members varied in terms of rhetorical moves. The researchers focused on the 12 rhetorical moves present in 1 out of 5 "About Us" sections of AAOU members' websites (see Table II). First, institutions introduced themselves by providing an overview that encapsulates their establishment and mandate. For some institutions, this move may also come with the indication of the institution's vision, mission, and goals. This was followed by a welcome message addressed to the visitors from the head of the institution. The message reiterated more on the thrust of the university, specifically on the programs offered that

\begin{tabular}{|c|c|c|}
\hline Rhetorical move & Communicative purpose & Sub-sections \\
\hline $\begin{array}{l}\text { Introducing the } \\
\text { institution }\end{array}$ & $\begin{array}{l}\text { Providing an overview of the institution through a number of } \\
\text { information about its history and mandate }\end{array}$ & Overview \\
\hline Greetings & Welcoming the visitors of the institution's website & President's message \\
\hline $\begin{array}{l}\text { Establishing } \\
\text { administrator's } \\
\text { suitability }\end{array}$ & $\begin{array}{l}\text { Letting the visitors know that the institution is being run by } \\
\text { a competent administrator with impressive credentials }\end{array}$ & President's profile \\
\hline Establishing integrity & Providing an ideal image of the institution & $\begin{array}{l}\text { Vision, mission } \\
\text { and goals }\end{array}$ \\
\hline $\begin{array}{l}\text { Establishing } \\
\text { accomplishments }\end{array}$ & $\begin{array}{l}\text { Providing an overview of the opportunities and challenges } \\
\text { taken and overcome by the institution over the years }\end{array}$ & History \\
\hline $\begin{array}{l}\text { Introducing the } \\
\text { administration }\end{array}$ & $\begin{array}{l}\text { Providing the visitors with information about the officials } \\
\text { who run the institution's offices }\end{array}$ & $\begin{array}{l}\text { Board of directors, } \\
\text { executive committee }\end{array}$ \\
\hline $\begin{array}{l}\text { Detailing } \\
\text { organizational } \\
\text { structure }\end{array}$ & $\begin{array}{l}\text { Providing the visitors with information about the functions } \\
\text { of the institution's offices }\end{array}$ & $\begin{array}{l}\text { Organization, } \\
\text { organizational chart }\end{array}$ \\
\hline $\begin{array}{l}\text { Supplying } \\
\text { organizational data }\end{array}$ & Providing facts and figures to describe the institution & Facts and Figures \\
\hline $\begin{array}{l}\text { Reinforcing } \\
\text { accomplishments }\end{array}$ & Providing information about current institutional milestones & $\begin{array}{l}\text { Achievements, } \\
\text { milestones }\end{array}$ \\
\hline Offering services & $\begin{array}{l}\text { Providing information about the services offered and } \\
\text { facilities available in the institution }\end{array}$ & Support and facilities \\
\hline Establishing contact & Providing lines of communication through different channels & $\begin{array}{l}\text { Contact Us, } \\
\text { campus location }\end{array}$ \\
\hline $\begin{array}{l}\text { Establishing influence } \\
\text { and connections }\end{array}$ & $\begin{array}{l}\text { Providing information about partner institutions } \\
\text { and networks }\end{array}$ & Linkages \\
\hline
\end{tabular}


visitors may consider for application. Initiatives to live up to the university's vision, mission, and goals were also discussed. AAOU members further introduced the head of institution by sharing his or her professional credentials which exemplified a prolific career in instruction, research, and public service. The aim of this move was to establish his or her suitability to govern the institution.

Once the head of the institution had been properly introduced, majority of the institutions also opted to provide a section that delineates their mission, vision, and goals. This served as a venue where an idealized image of the institution was described and where integrity was being established by mentioning the principles that guide the institution. This rhetorical move was followed by the establishment of the institution's accomplishments through its historical milestones achieved by the institution as a whole or by the members of its community.

More details were provided through the introduction of the officials in charge of the offices in the institution. This was followed by the provision of the key functions of each of these offices through organizational charts which showed the supra-system and sub-systems that worked interdependently towards achieving the institution's vision, mission, and goals. More facts and statistics were then provided along with current milestones on the instruction, research, and public service thrusts of the universities.

The next move of the "About Us" sections was geared more toward an attempt to interact with the websites' visitors. This was accomplished through the rhetorical move of offering services through various physical and online facilities and establishing contacts through the provision of office addresses, e-mail addresses, and social media accounts. The last move is to show influence and connections with other institutions of similar mandates by providing information regarding institutional linkages.

It can be deduced that the rhetorical moves employed by AAOU members also resembled those that were mapped by Zhang (2017) in his dissection of the "About Us" sections of Chinese university websites. Some similarities with rhetorical moves in Yang (2013) and Askehave and Nielsen (2005) were also evident. This shows that the "About Us" sections of AAOU members' websites exemplified a promotional culture that relied on authoritarian and inclusive portrayals. The former can be seen in the rhetorical moves that emphasized on information about AAOU members' history and mandate, suitability of administrators, commitment to integrity, structure and functions of the organization, reinforcement of institutional accomplishment, and display of influence through networks and linkages. Meanwhile, inclusivity was shown through the welcome message from the President or Chancellor as well as the offer to provide services and the invite to visit the campus and connect through available channels.

\subsection{Keyword analysis}

The analysis in AntConc (Anthony, 2017) yielded a total of 193,218 words and 7,300 words, when collated. Among these, only 2,974 were calculated as keywords with significant statistical and effect size differences. An overwhelming majority of these keywords had positive keyness. As delineated in the methodology, the researchers decided to eliminate words such as linking verbs, articles, prepositions, and conjunctions (please see Appendix to find the top 100 keywords with positive keyness). A categorization of these keywords showed that AAOU members emphasized the salient characteristics of open and distance education. These can be seen in the high and positive keyness of words "open" and "distance" as well as the words "online" and "face" which were used to indicate blended modes of learning (face-to-face plus online mode of learning).

The choice of pronouns also resonated with Fairclough (1993 as cited in Yang, 2013) specifically the use of collective pronouns such as "their" and "our." It could also be deduced that AAOU members are still highly masculine, as exemplified by the high positive keyness 
AAOUJ

13,1

of the pronoun "his." Yang's (2013) findings that pertained to the use of positive adjectives were also evident in the "About Us" sections of AAOU members. Words with negative denotations (e.g. "no," "not," or "without") were not used as much as "all," "first," "has," "have," "more," and "well." Same focus was given to verbs that denote positive actions such as "achieve," "ensure," "provide," "providing," "service," and "signed."

Apart from the attempt to distinguish open universities from others through the mode of learning and the worldview of openness, the "About Us" sections of AAOU members' websites still used words that often characterized universities in general, such as "international," "quality," "system," "established," national," and "professional," among others. Physical and online facilities were also mentioned (e.g. "campus," "centers," and "institute"). Aside from these characteristics, a bulk of the Top 100 keywords with positive keyness pertained to the thrusts of the universities: academic (e.g. "learning", "knowledge," "students," "programs," "study," "teaching," course," "degree," "faculty," "learners," "professor," and "registration," among others), research and public service (e.g. "research," "public" and "policy"). There were also keywords that referred to the administration of the universities (e.g. "financial," "Chancellor," "mutual," "understanding," "division," "President," "council," "business," "department," "memorandum," "vice," and "control") whereas some cut across areas in the universities' mandates (e.g. "development," " management," "technology," "services," "resources," "activities," and "plan"). The universities' objective to have societal impact was also apparent in the words "society," "state," "country," "social," "world," and "Asia," among others.

In terms of negative keyness, majority of the results were letters that served as enumerators (i.e. "a." "b." "c." among others). The pronoun "I" was also found to occur least in the "About Us" section. This could be attributed to the fact that the said pronoun countered the personalization of the universities as collective entities. Hence, the use of the pronoun "I" was only limited to the second rhetorical move which was carried out through the welcoming message of the organization head.

\subsection{Concordance analysis}

As articulated in the methodology, there were 7,300 words yielded by the concordance function of AntConc (Anthony, 2017), and the researchers agreed to only select those that were related to AAOU 2017 Conference's main theme and sub-themes. This was done to ensure that the study is in line with what the AAOU deemed as important trends in the field of open and distance education. After deliberations, the following words were selected: open or openness; access, accessible, or accessibility; assessment; quality; inclusive or inclusivity; equal or equality; equity or equitable; and justice. Illustrative quotes as to how these words were used in the websites are shown in Table III.

4.3.1 Open or openness. In the "About Us" section of AAOU members' websites, the word "open" managed to have a high ranking and positive keyness primarily because the word was part of the universities' names as well as the area or field of study of the academics working in the universities. The philosophy of openness is said to permeate all facets of open and distance education. However, Alfonso (2014b) pointed out that the concept of openness should be deemed as a moving target that goes beyond the eradication of barriers to learning. It should also adopt to the advancement of information and communication technology (ICT) in education. Further, Hug (2017) argued that understanding the concepts and contexts of openness is a must to spark informed debates on organizational, methodological, and critical aspects of higher education.

With this in mind, the researchers found and analyzed the varying contexts wherein AAOU members used the word open. In the AAOU members' websites, the word open was referred to as follows: the accessibility of services, facilities, and materials; an adjective to 


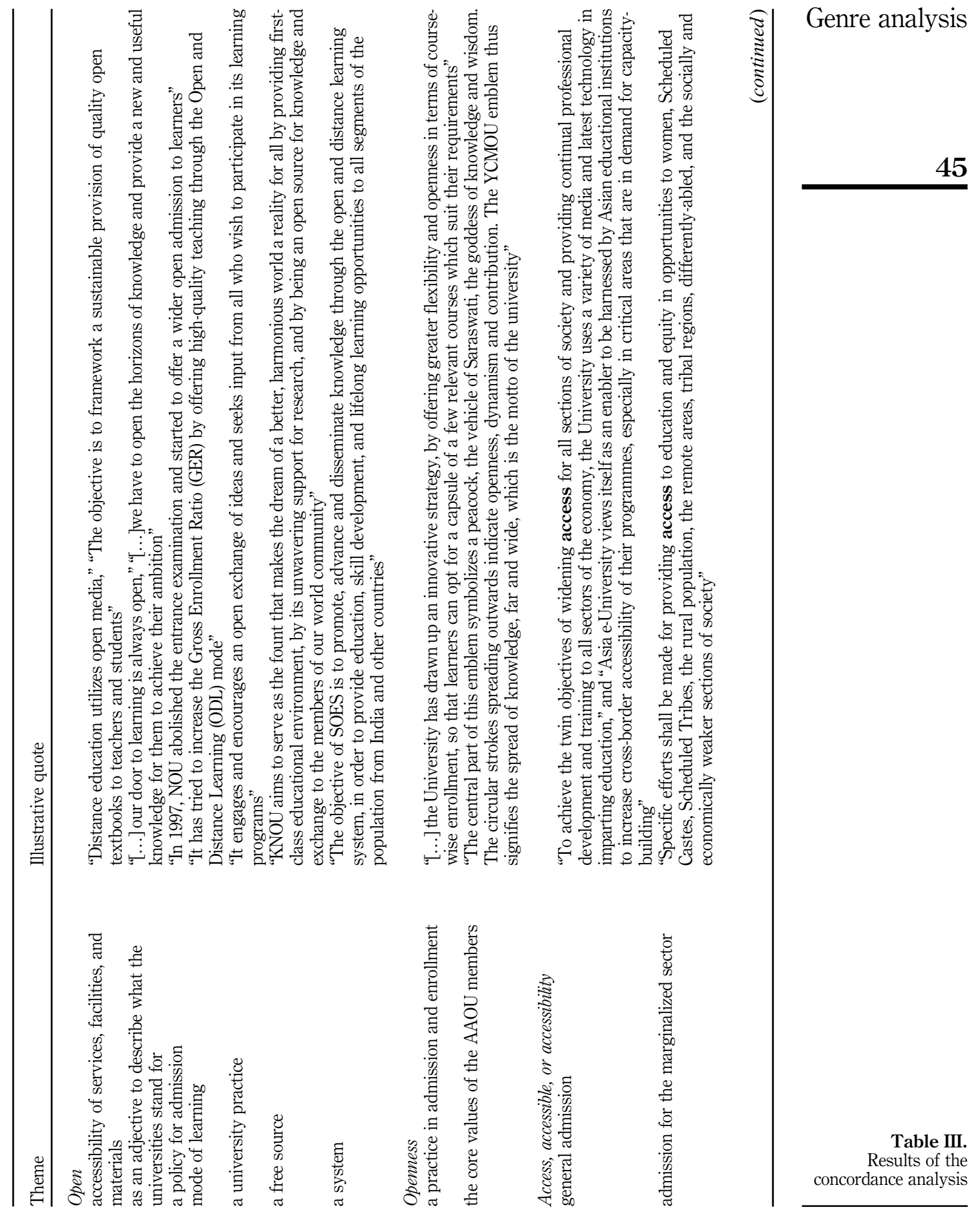


AAOU
13,1

46

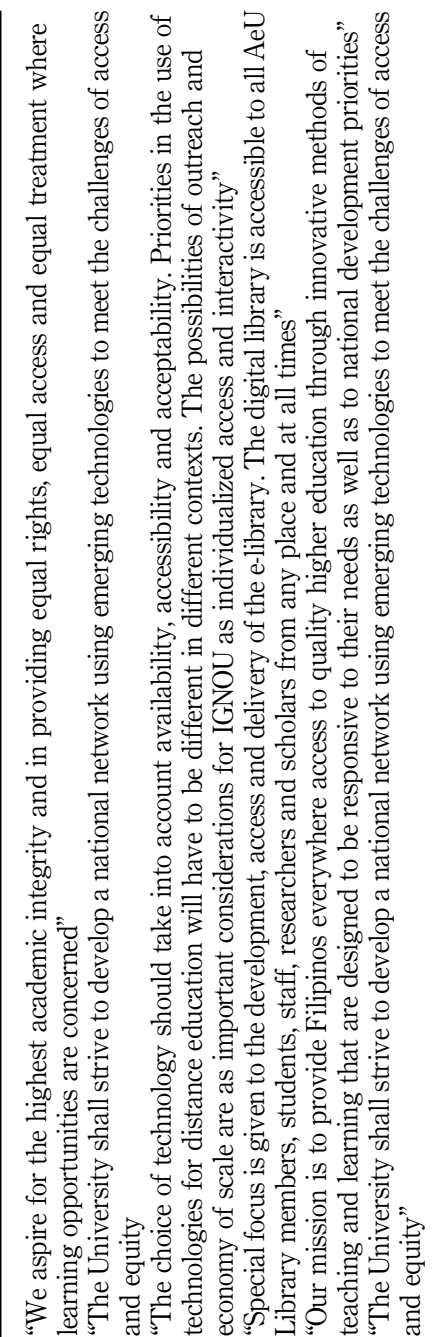

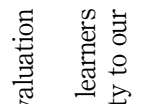

山্口

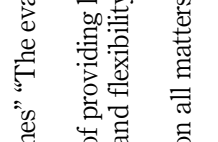

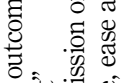

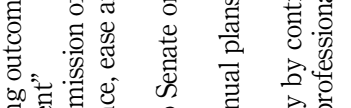

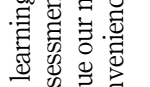

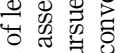

: :

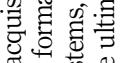

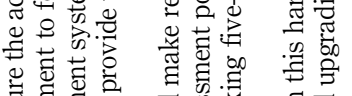

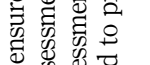

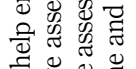

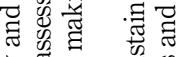

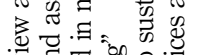

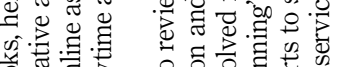

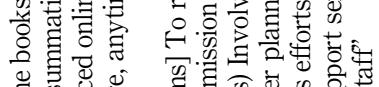

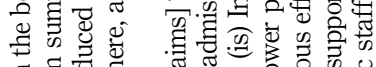

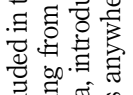

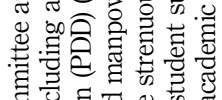

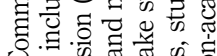

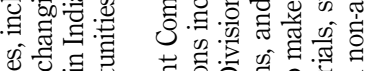

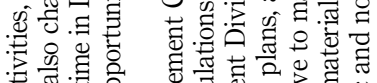

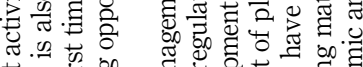

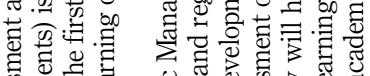

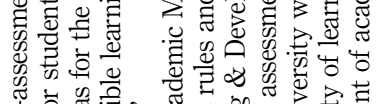

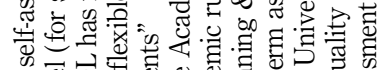

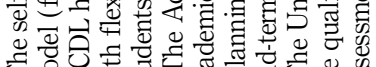

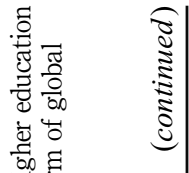

.

눙 胥

몰

일.

胥芯

氙.

记

芑

灵 등

艺兒总

हते है

怘芯

导严

률휴

吾论

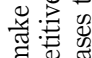

言芯

突芯

슬요용

컹

웜

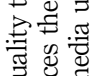

己

렬 ్ㅗㅇ

管家

焉菉䓌

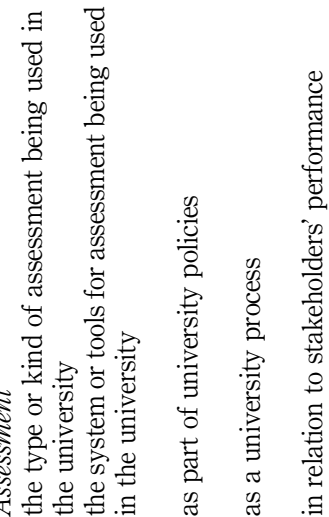

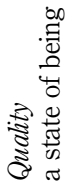




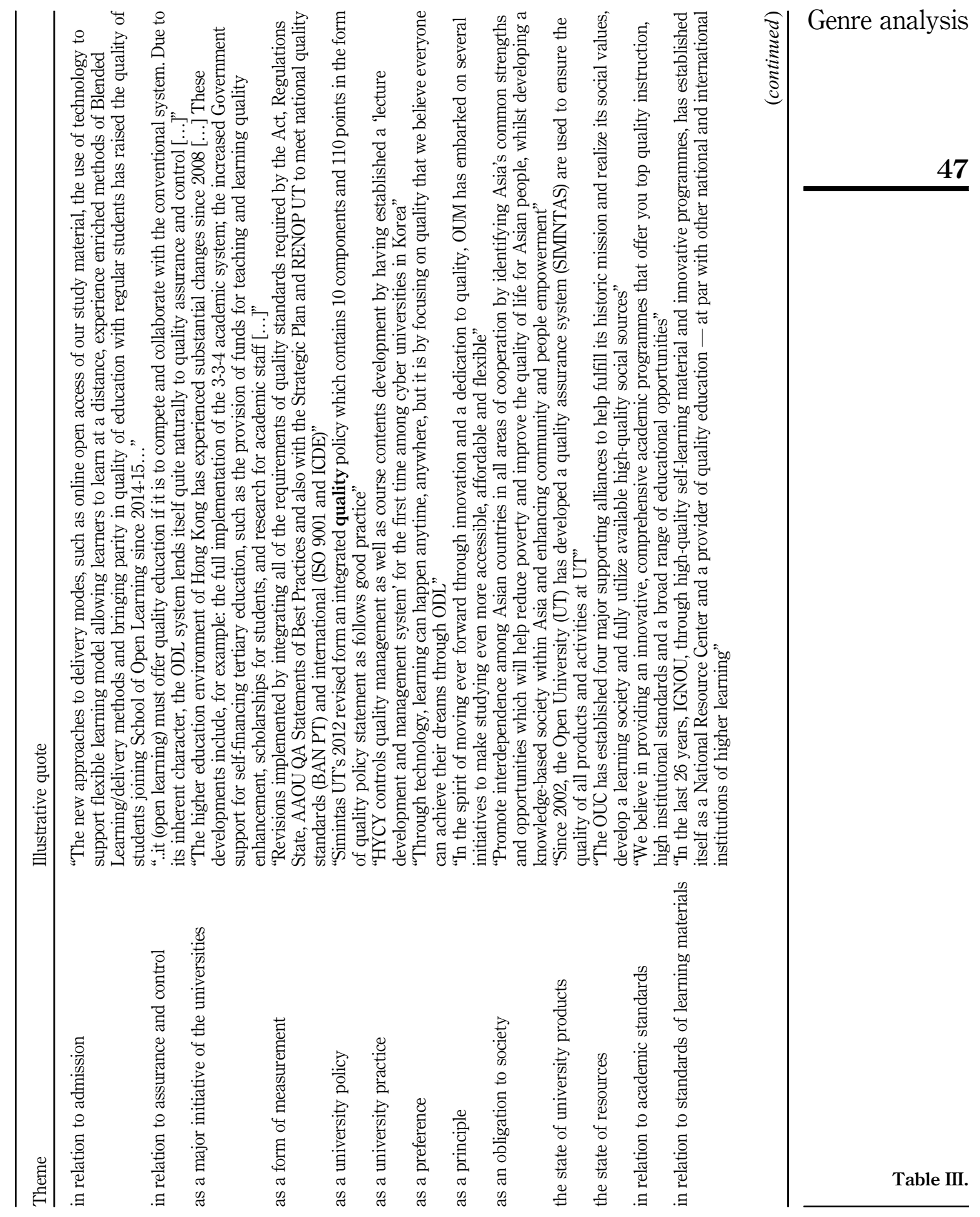




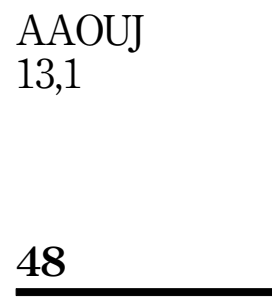

Table III.

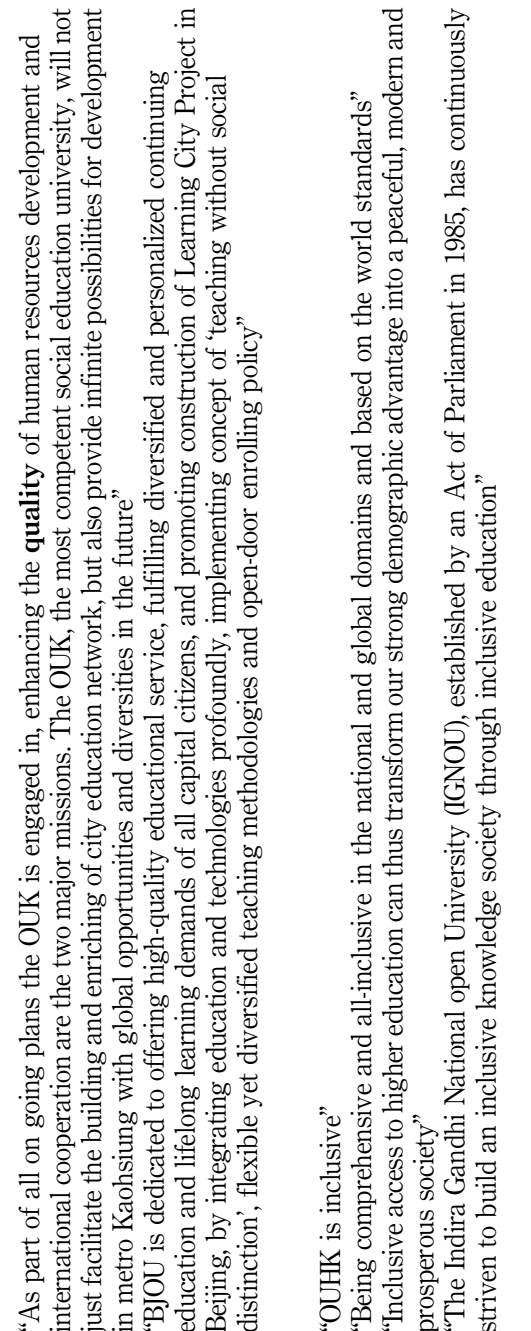

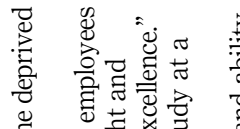

至

¿

ज

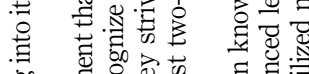

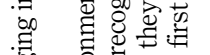

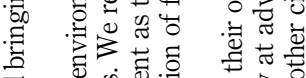

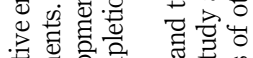

过

. के क

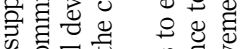

की

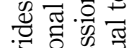

on

范范

i.:

武焉爮

可的

寻 寻

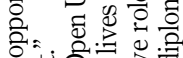

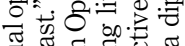

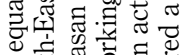

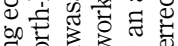

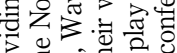

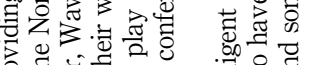

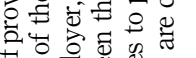

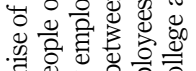

है.

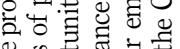

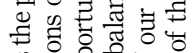

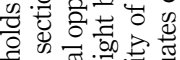

我西.

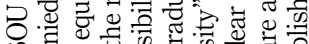

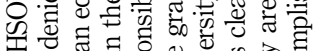

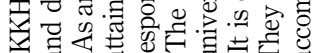

o.

范茟

寻

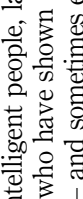

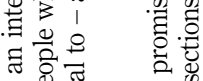

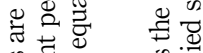

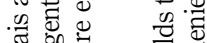

뭉

空 츤

焉

皕密

害导

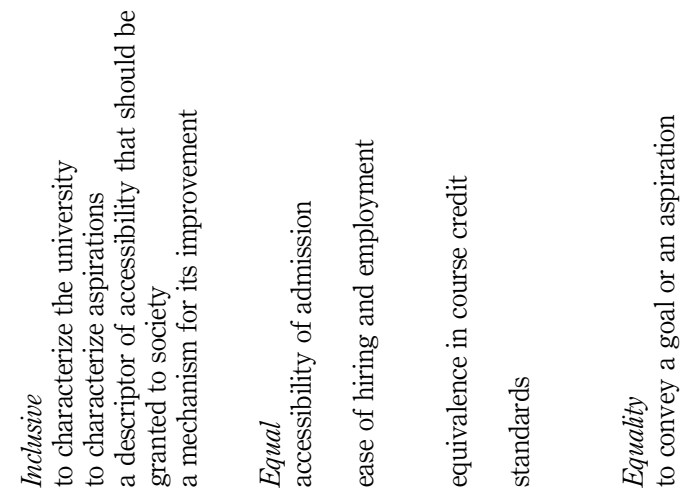




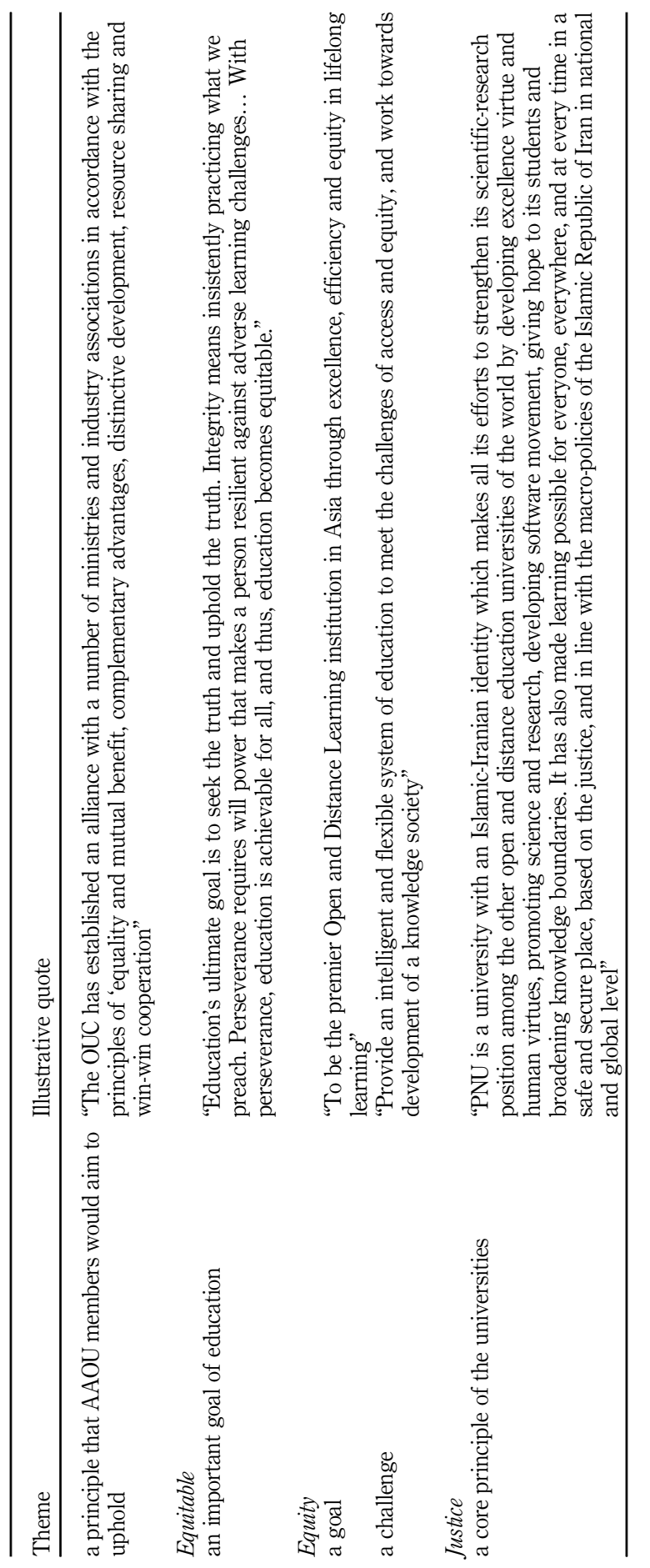

Genre analysis

49

Table III. 
AAOUJ

13,1

describe what the universities stand for; a policy for admission; a mode of learning; a university practice; a free source; or a system (Table III).

While the word "open" was mentioned more than 400 times (ranked 9th) in the "About Us" sections of AAOU members' websites, "openness" was only used five times (ranked $1833 \mathrm{rd}$ ), once as a proper name for a program, another as a practice in admission and enrollment and thrice with regard to the core values of the AAOU members (Table III).

4.3.2 Access, accessible, or accessibility. The United Nations Educational, Scientific, and Cultural Organization (2016) considers accessibility as one of the key pillars for lifelong education. Furthermore, Carlsen et al. (2016) through the United Nations Educational, Scientific, and Cultural Organization also discussed about the roles that open and distance learning institutions have served in ensuring accessibility of quality education. However, they also reported that barriers continually exist and must be addressed to reach more learners. In this regard, scholars and practitioners in open and distance learning institutions must continuously thicken the discourse on accessibility to serve as basis for action towards emerging and evolving issues.

In the AntConc (Anthony, 2017) wordlist for the "About Us" sections of AAOU members' websites, the word "access" ranked 142nd $(n=59)$ while "accessible" and "accessibility" ranked 624th $(n=16)$ and 2285th $(n=3)$, respectively. The contexts where these words were used were categorized as follows: general admission; admission for the marginalized sector; in relation to equality; in relation to equity; in relation to academic instruction, services and facilities; attainment of higher education and quality education; and a challenge (Table III).

4.3.3 Assessment. Scholars and practitioners have deemed assessment as an integral part of open and distance learning. Chaudhary and Dey (2013) emphasized that assessment is needed not just to serve as basis for grading students; it is also a means to determine the effectiveness of the programs, courses, and other related initiatives. Moreover, assessment plays a crucial role in developing students' positive attitudes and behaviors in an open and distance education setting. While open and distance learning institutions vary in their assessment practices, Chaudhary and Dey (2013) reiterated that it is always a collaborative effort between the teachers and the students, and issues such as credibility and reliability must be addressed. Flor and Flor (2016) argued that open and distance learning institutions must also evaluate their assessment practices to best address the diversity of students. Given the efforts needed to ensure that assessment fits the contexts of both students and teachers, scholars and practitioners of open and distance education must continue reflecting about their assessment practices.

In the "About Us" sections of AAOU members' websites, the word "assessment" appeared 25 times and ranked 388th among the keywords with positive keyness. The word was used as a proper noun for councils and departments and as faculty members' field of expertise. Aside from these, AAOU members also talked about "assessment" in the following contexts: the type or kind of assessment being used in the university, the system or tools for assessment being used in the university, as part of university policies, as a university process, and in relation to stakeholders' performance (Table III).

4.3.4 Quality. It is said that open and distance learning institutions still need to concretize their notions of quality (Belawati, 2008 as cited in Alfonso, 2014a). The AAOU (n.d.c) has published its quality assurance framework which covers the best practices in the following areas: policy and policy planning; internal management; learner and learners' profiles; infrastructure, media, and learning resources; learner assessment and evaluation; research and community services; human resources; learner support; program design and curriculum development; and course design and development. While the AAOUquality assurance framework has been conceptualized, scholars and practitioners still continue the discourse on quality. As Belawati and Zuhairi (2007) pointed out, quality is a continuous process that relies heavily on people's commitment. 
Aside from the words "open," "international," and "distance," "quality” also got one of the highest positive keyness, and it was ranked 21st in terms of usage $(n=192)$. Through concordance analysis, the researchers found that the word "quality" was used a lot and in different ways: a state of being; in relation to admission; in relation to assurance and control; as a major initiative of the universities; as a form of measurement; as a university policy; as a university practice; as a preference; as a principle; as an obligation to society; the state of university products; the state of resources; in relation to academic standards; in relation to standards of learning materials; in relation to human resources standards; and in relation to standards of university services (Table III).

4.3.5 Inclusive or inclusivity. The United Nations Sustainable Development Goal aims to "ensure inclusive and quality education for all and promote lifelong learning" (United Nations, n.d.). In particular, United Nations Educational, Scientific, and Cultural Organization (2016) called upon open and distance learning institutions to lead the initiatives targeted towards inclusion of people with disabilities. However, Kanwar and Cheng (2017) of the Commonwealth of Learning claimed that while open and distance learning is a key player in providing access to the marginalized and the disabled, inclusion could not solely be addressed by open and distance learning's reliance on ICT. Accordingly, much must still be done to ensure that inclusivity covers not just ICT, but also materials and pedagogy among others. More importantly, Kanwar and Cheng (2017) emphasized that scholars and practitioners must build their capacity to continually exercise inclusion in the learning space.

The word inclusivity was not used in the "About Us" sections of AAOU members' websites, but the word "inclusive" appeared seven times and ranked 1370th among the keywords with positive keyness. AAOU members used "inclusive" both to characterize themselves and their aspirations. "Inclusive" was also a descriptor of accessibility that should be granted to society and also a mechanism for its improvement (Table III).

4.3.6 Equal or equality. Open and distance learning institutions have been perceived as an alternative that could address the problems of inequality and inequity (Goswami, 2013). However, The Open University (2016) pointed out that open and distance learning scholars and practitioners must clarify what they mean by related concepts such as equality and equity among others. McMillan and Cottom (2015, as cited in Makoni, 2015) further explained that while open and distance learning is a powerful mechanism against inequality, a lot must be done to make the system and the environment more robust to widen the access and cater more to the disadvantaged.

In the "About Us" sections of AAOU members' websites, the words "equal" and "equality" were both deemed as keywords. "Equal" occurred 14 times while "equality" was used four times. These words ranked 730th and 2015th in the words with positive keyness, respectively. Uses of the word "equal" were related to the following: accessibility of admission, ease of hiring and employment, equivalence in course credit, and standards (Table III). With regard to the word "equality," it was used to convey a goal or an aspiration as well as a principle that AAOU members would aim to uphold (Table III).

4.3.7 Equitable or equity. Apart from inclusivity, equity is another primary concern of the UN Sustainable Development Goal for education. Alfonso (2014a, b) pointed out that equity is more attuned with open and distance learning. This could be attributed to the fact that in the history of open and distance learning, equity is perceived to be tantamount to access. While such provides an important facet in the policies of open and distance learning institutions, Yasmin (2010) calls for the continual and integral consideration of equity in other aspect of open and distance learning.

The word "equitable" was mentioned only once and was not considered as a keyword with positive or negative keyness. Meanwhile, the word "equity" appeared four times and 
AAOUJ

13,1

ranked 2016th among the keywords with positive keyness. Unlike the words "equal" or "equality," the discourse on equity was not as evident in the "About Us" section of AAOU members' website. In discussing the motto that the institution had been trying to live up to, the Open University of Hong Kong reiterated about being "equitable" as an important goal of education (Table III).

In the use of the word "equity," it can be observed that AAOU members considered "equity" as both a goal and a challenge (Table III).

4.3.8 Justice. Open and distance learning has been regarded as an instrument to achieve social justice. However, despite its emphasis on access and equity, open and distance learning is still mired with barriers that prevent potential and current learners to maximize its affordances (Fadlahllah, 2011). Tait (2013) argued that the mission statements of open and distance learning institutions must be revisited, rethought, updated, and clarified since claims of commitment to development and social justice appeared to be "unsupported or naive." Tait (2013) also encouraged the continuation of discourses pertaining to development and social justice with hopes that this could go beyond rhetoric.

In the present study, the researcher found that much like the word "equity," the word "justice" was also mentioned 4 times and ranked $2084^{\text {th }}$ among the keywords with positive keyness. However, it would be important to note that the use of the word "justice" was very limited in the "About Us" sections of AAOU members' websites. In two concordance lines, the word "justice" pertained to positions taken by members of the universities. The other two concordance lines discussed "justice" as a core principle of the universities, specifically of the Open University of Hong Kong and the Payame Noor University in Iran (Table III).

Based on the concordance analysis, it can be deduced that AAOU members had been active in the discourse about accessibility, assessment, and quality. However, it remains unclear how AAOU members define openness. This is crucial since it is inherently at the core of the existence of open universities. In the same way, there is not much discourse on how inclusive AAOU members should be and the key measures and indicators that can aid AAOU members in determining if they are upholding and practicing the said principle. The debate between equality and equity should also become a point of discussion among AAOU members in order to clarify where the association and individual universities stand. The concordance analysis showed that AAOU members saw equality as a goal, aspiration, and principle. Meanwhile, equity was deemed as a goal and also a challenge to overcome. If the AAOU members opted to strive for equity as part of their worldview and practice, support should be in place in order to ensure that equity can be materialized. Lastly, justice seemed to be an elusive topic in the "About Us" sections of AAOU members' websites. This should be another point of discussion among AAOU members as open education could be a solution that would address the social injustice that arises out of inequalities in the distribution of access to knowledge.

\section{Conclusion}

The current study aimed to dissect the academic web genre as exemplified by AAOU members in their respective "About Us" sections. A three-part genre analysis was done. First, the move analysis resonated with the results previously found by scholars who also conducted similar studies of academic web genre. The 12 rhetorical moves used to achieve the communicative purpose of the "About Us" sections also showed the promotional nature of university websites in a manner that was both authoritarian and inclusive (Yang, 2013; Zhang, 2017).

Meanwhile, the keyword analysis revealed the use of words inherent in open and distance education. However, majority of the keywords with positive keyness were also words that characterized both residential and distance education institutions. The use of 
words with positive connotations was also contributory to the promotional nature of the Genre analysis academic web genre.

Lastly, the concordance analysis showed the contexts wherein words were used by AAOU members in order to make sense of social realities. It also revealed topics that should be further discussed in order to improve the sense of identities of AAOU members as well as their commitment to provide services that are in line with their academic, research, and public service thrusts. The depth of insights found in the concordance analysis echoed Caiazzo's (2009, as cited in Yang, 2013) conviction regarding the use of corpus linguistics in the study of university web genre.

In conclusion, the findings from the move analysis and keyword analysis show that the "About Us" sections of the AAOU members' websites generally serve as the universities' vehicles for promotion and distinction. However, results of the concordance analysis show diversity in the AAOU member universities' use of words that are deemed as important trends in the field of open and distance education,. This demands continuous discourse among AAOU members to enrich the understanding of these trends in the field. It is suggested that the "About Us" sections of the university websites be used as a platform to not just promote and distinguish the institutions, but also reflect the philosophy of open and distance learning. This is to provide substantial information to stakeholders, many of which are still not cognizant to the values and principles that open and distance institutions subscribe to.

In the future, researchers are also encouraged to conduct case studies of individual university websites, but with the inclusion of all the sections and sub-sections. This would entail the support and participation of data mining professionals who could cull large amounts of electronic texts efficiently via programming. In terms of genre analysis, researchers may also include an examination of multimodality (the different modes used in composing online messages), intertextuality (the relationship among online texts and other parts of the websites), and steps in each rhetorical move of university websites.

A comparison of corpora from open and distance learning institutions and residential universities may also be explored. This will need mining and aggregating electronic texts from both corpora and loading these to an open-sourced text analysis software like Antconc (Anthony, 2017). Achievement of communication purpose should also be determined through evaluation of the university websites and opinion surveys with the target audience. These recommendations as well as the findings of the current study will serve as effective guides to open and distance education institutions in terms of improving and maximizing the impact of their presence online via their university websites.

\section{References}

Alfonso, G.J. (2014a), "Creating spaces and possibilities through open and distance elearning (ODeL): a worldview", in Alfonso, G.J. and Garcia, P.G. (Eds), Open and Distance e-learning: Shaping the Future of Teaching and Learning, University of the Philippines Open University, Los Banos, pp. 3-14.

Alfonso, G.J. (2014b), "Open educational resources and massive open online courses", in Alfonso, G.J. and Garcia, P.G. (Eds), Open and Distance e-learning: Shaping the Future of Teaching and Learning, UP Open University, Los Banos, pp. 101-114.

Al-Khasawneh, F.M. (2017), "A genre analysis of research article abstracts written by native and non-native speakers of English”, Journal of Applied Linguistics and Language Research, Vol. 4 No. 1, pp. 1-13, available at: www.jallr.com/index.php/JALLR/article/view/490/pdf490 (accessed August 12, 2017).

Anthony, L. (2017), “AntConc (3.5.0)", available at: www.laurenceanthony.net/ (accessed August 1, 2017).

Asian Association of Open Universities (2017), "Call for papers”, available at: http://aaou2017.ut.ac.id/ call-for-papers/ (accessed June 8, 2017). 
AAOUJ 13,1

Asian Association of Open Universities (n.d.a), "Associate members", available at: http://aaou.upou. edu.ph/associate-members/ (accessed April 21, 2017).

Asian Association of Open Universities (n.d.b), "Full members", available at: http://aaou.upou.edu.ph/ full-members/ (accessed April 21, 2017).

Asian Association of Open Universities (n.d.c), "Quality assurance framework", available at: http://aaou.upou.edu.ph/quality-assurance-framework/ (accessed February 2, 2018).

Askehave, I. and Nielsen, A.E. (2005), "What are the characteristics of digital genres? - Genre theory from a multi- modal perspective", paper presented at 38th Hawaii International Conference on System Sciences, Big Island, HI, January 3-6 , available at: www.computer.org/csdl/proceedings/hicss/200 5/2268/04/22680098a.pdf (accessed April 21, 2017).

Barrett, D. (2007), "The War on terror - an intentional choice of words? a corpus analysis of war on and war against", paper presented at Corpus Linguistic Conference, University of Birmingham, Birmingham, July 27-30, available at: www.birmingham.ac.uk/documents/college-artslaw/corpus/ conferencearchives/2007/20Paper.pdf (accessed August 12, 2017).

Belawati, T. and Zuhairi, A. (2007), "The practice of a quality assurance system in open and distance learning: a case study at universitas Terbuka Indonesia (The Indonesia Open University)", International Review of Research in Open and Distance Learning, Vol. 8 No. 1, pp. 1-14, available at: www.irrodl.org/index.php/irrodl/article/view/340/774 (accessed February 2, 2018).

Benham, B. and Golpour, F. (2014), "A genre analysis of English and Iranian research articles abstracts in applied linguistics and mathematics", International Journal of Applied Linguistics and English Literature, Vol. 3 No. 5, pp. 173-179, available at: www.journals.aiac.org.au/index.php/IJALEL/ article/view/1143/1207 (accessed August 12, 2017).

Bhatia, V.K. (1997), "Genre analysis today", Revue Belge de Philologie et d'Histoire, Vol. 75 No. 3, pp. 629-652, available at: www.persee.fr/doc/rbph_0035-0818_1997_num_75_3_4186 (accessed June 8, 2017).

Carlsen, A., Holmberg, C., Neghina, C. and Owusu-Boampong, A. (2016), "Closing the gap: opportunities for distance education to benefit adult learners in higher education", available at: http://unesdoc. unesco.org/images/0024/002432/243264e.pdf (accessed February 2, 2018).

Cermakova, A. (2015), "Repetition in John Irving's novel a widow for one year", International Journal of Corpus Linguistics, Vol. 20 No. 3, pp. 355-377.

Charteris-Black, J. (2012), "Comparative keyword analysis and leadership communication: Tony blair a study of rhetorical style", in Helms, L. (Ed.), Comparative Political Leadership. Palgrave Studies in Political Leadership Series, Palgrave Macmillan, London, pp. 142-164.

Chaudhary, S.V.S. and Dey, N. (2013), "Assessment in open and distance learning (ODL) system: a challenge", Open Praxis, Vol. 5 No. 3, pp. 207-216, available at: https://openpraxis.org/index.php/ OpenPraxis/article/view/65/47 (accessed February 2, 2018).

Clark, C. (2011), "Either you are with us, or you are with terrorists': how UK and US television news reported the 2003 Iraq conflict", in Morley, J. and Bayley, P. (Eds), Corpus-assisted Discourse Studies on the Iraq Conflict: Wording the War, Routledge, New York, NY, pp. 142-165, available at: https://books.google.com.ph/books?id=u0KPAgAAQBAJ\&pg=PT258\&lpg=PT258\&dq= war+in+iraq+keyword+analysis+morley+and+bayley\&source $=$ bl\&ots $=8 \mathrm{wHvx} 7 \mathrm{pW6n} \&$ sig=19yVk_tkv7OnCReDFLd08GYvqZI\&hl=en\&sa=X\&ved=0ahUKEwiOyeGxqeDVAhXIe rwKHc8-DLkQ6AEIJjAA\#v=onepage\&q=war \%20in \%20iraq \%20keyword $\% 20$ analysis $\%$ 20morley\%20and\%20bayley\&f=false (accessed August 12, 2017).

Cross, C. and Oppenheim, C. (2006), "A genre analysis of scientific abstracts”, Journal of Documentation, Vol. 62 No. 4, pp. 428-446, available at: https://doi.org/10.1108/00220410610700953 (accessed May 12, 2017).

Culpeper, J. (2009), "Keyness: words, parts-of-speech and semantic categories in the character-talk of Shakespeare's Romeo and juliet”, International Journal of Corpus Linguistics, Vol. 14 No. 1, pp. 29-59.

Ding, H. (2007), "Genre analysis of personal statements: analysis of moves in application essays to medical and dental schools", English for Specific Purposes, Vol. 26 No. 2007, pp. 368-392. 
Fadlahllah, A. (2011), "Bridging the gap in digital divide", Fourteenth Cambridge International Conference on Open and Distance e-Leanning, Cambridge, September 25-28, available at: www. vhi.st-edmunds.cam.ac.uk/events/past-events/conferences/CDE-conference/CDE-Papers/2011authorsF-L (accessed February 10, 2018).

Fischer-Starcke, B. (2009), "Keywords and frequent phrases of Jane Austen's pride and Prejudice", International Journal of Corpus Linguistics, Vol. 14 No. 4, pp. 492-523.

Flor, A.G. and Flor, B.G. (2016), "Dysfunctional digital demeanors: tales from (and policy implications of) elearning's dark side", in Eby, G., Yuzer, T.V. and Atay, S. (Eds), Developing Successful Strategies for Global Policies and Cyber Transparency in e-learning, IGI Global Academic Publishers, Hershey, PA, pp. 46-59.

Gabrielatos, C. and Marchi, A. (2012), "Keyness: appropriate metrics and practical issues", paper presented at CADS International Conference 2012. Corpus-assisted Discourse Studies: More than the sum of Discourse Analysis and computing?, University of Bologna, Bologna, September 13-14, available at: https://repository.edgehill.ac.uk/4196/ (accessed August 12, 2017).

Goswami, A. (2013), "Role of distance education and open learning in higher education", International Journal of Humanities and Social Science Invention, Vol. 2 No. 9, pp. 79-80, available at: www. ijhssi.org/papers/v2(9)/Version-1/N0291079080.pdf (accessed February 2, 2018).

Heaton, D. (2010), "Scraper”, available at: https://github.com/mnmldave/scraper (accessed May 12, 2017).

Hug, T. (2017), "Openness in education: claims, concepts, and perspectives for higher education", International Journal of Media, Technology, and Lifelong Learning, Vol. 13 No. 2, pp. 73-87, available at: https://journals.hioa.no/index.php/seminar/article/view/2308/2120 (accessed February 2, 2017).

Isa, N.M., Ali, A.Z.M., Fadzillah, F.I.M. and Mohamad, J.B. (2016), "A genre analysis of corporate websites of oil and gas companies", Journal of Education and Social Sciences, Vol. 6 No. 2, pp. 263-270, available at: http://jesoc.com/wp-content/uploads/2017/05/KC6-14.pdf (accessed April 21, 2017).

Jalilifar, A., Mehrabi, K. and Mousavinia, S.R. (2014), "The effect of concordance enriched instruction vocabulary learning and retention of iranian EFL learners", Procedia - Social and Behavioral Sciences, Vol. 98, Clemson, SC, pp. 742-746, available at: https://doi.org/10.1016/j.sbspro.2014.03. 476 (accessed August 12, 2017).

Jessee, A. (2009), "Strategic stories: an analysis of the profile genre", unpublished master's thesis, Clemson University, available at: http://tigerprints.clemson.edu/cgi/viewcontent.cgi?article= 1550\&context=all_theses (accessed August 12, 2017).

Jimenez-Crespo, M.A. (2011), "To adapt or not to adapt in web localization: a contrastive genre-based study of original and localised legal sections in corporate websites", The Journal of Specialized Translation, No. 15, pp. 2-27, available at: www.jostrans.org/issue15/art_jimenez.pdf (accessed August 12, 2017).

Johari, M.D.M. and Ali, A.M. (2015), "The business web genre: a genre analysis on the websites of selected Malaysian small and medium enterprises (SMEs)", in Omar, R., Bahrom, H. and de Mello, G. (Eds), Islamic Perspectives Relating to Business, Arts, Culture and Communication, Springer, Singapore, pp. 383-404.

Kanwar, A. and Cheng, R.Z. (2017), "Making open and distance learning inclusive: the role of technology", 6th International Conference on Information and Communication Technology and Accessibility, Muscat, December 20, available at: http://oasis.col.org/bitstream/handle/11599/2827/2017_ Kanwar-Cheng_Making-ODL-Inclusive_Transcript.pdf?sequence=6\&isAllowed=y (accessed February 10, 2018).

Kent State University (n.d.), “Corpus linguistics glossary”, available at: www.kent.edu/appling/corpuslinguistics-glossary (August 12, 2017).

Li, Y. (2011), "A genre analysis of English and Chinese research article abstracts in Linguistics and Chemistry", unpublished master's thesis, San Diego State University, San Diego, CA, available at: http://scholarworks.calstate.edu/bitstream/handle/10211.10/1128/Li_Yun.pdf; sequence $=1$ (accessed August 12, 2017). 
AAOUJ 13,1

Makoni, M. (2015), "Education expansion can balance access with equality”, University World News, October 15, available at: www.universityworldnews.com/article.php?story=20151015175215385 (accessed February 3, 2018).

Marefat, H. and Mohammadzadeh, S. (2013), "Genre analysis of literature research article abstracts: a cross-linguistic, cross-cultural study", Applied Research on English Language, Vol. 2 No. 2, pp. 37-49, available at: http://are.ui.ac.ir/article_15469_eb57d34d17992ef62c9616e6a9416788.pdf (accessed August 12, 2017).

Nasseri, D. and Nematollahi, B. (2014), "A contrastive genre analysis of abstract of master of arts thesis in applied linguistics written by native and non-native speakers of English with respects to moves and move markers", Indian Journal of Science and Research, Vol. 7 No. 1, pp. 1353-1366, available at: www.ijsr.in/upload/312949916Microsoft\%20Word\%20-\%20paper\%20537.pdf (accessed August 12, 2017).

Niu, G. (2013), "A genre analysis of Chinese and english abstracts of academic journal articles: a parallel-corpus-based study", in Liu, P. and Su, Q. (Eds), Chinese Lexical Semantics. CLSW 2013. Lecture Notes in Computer Science, Vol. 8229, Springer, Berlin, Heidelberg, pp. 603-616, available at: https://link.springer.com/chapter/10.1007/978-3-642-45185-0_63 (accessed August 12, 2017).

Nordquist, R. (2017), "Rhetorical move", available at: www.thoughtco.com/rhetorical-move-1691917 (accessed June 8, 2017).

Pho, P.D. (2013), "Approaches to genre analysis", in Pho, P.D. (Ed.), Authorial Stance in Research Articles, Palgrave Macmillan, London, pp. 10-20.

Samraj, B. and Monk, L. (2008), "The statement of purpose in graduate program applications: genre structure and disciplinary variation”, English for Specific Purposes, Vol. 27 No. 2, pp. 193-211, available at: https://doi.org/10.1016/j.esp.2007.07.001 (accessed August 12, 2017).

Scott, M. (2008), WordSmith Tools version 5, Lexical Analysis Software, Liverpool.

Scott, M. (2015), "WordSmith tools manual", available at: http:/lexically.net/downloads/version6/ wordsmith6.pdf (accessed August 12, 2017).

Swales, J.M. (1990), Genre Analysis: English in Academic and Research Settings, Cambridge University Press, Cambridge.

Tait, A. (2013), "Distance and e-learning, social justice, and development: the relevance of capability approaches to the mission of open universities", The International Review of Research in Open and Distributed Learning, Vol. 14 No. 4, pp. 1-18, available at: www.irrodl.org/index.php/irrod1/ article/view/1526/2632 (accessed February 10, 2018).

Talebzadeh, S., Samar, R.G., Kiany, A. and Akbari, R. (2013), "Steps to a successful abstract: a comparative genre analysis", The International Journal of Humanities, Vol. 20 No. 3, pp. 1-25, available at: http://eijh.modares.ac.ir/article_11013_43f30cb798ccf5626c2f444d75f3d673.pdf (accessed August 12, 2017).

The British National Corpus (2007), "Distributed by bodleian libraries", version 3 (BNC XML Edition), University of Oxford, Oxford, available at: www.natcorp.ox.ac.uk/ (accessed May 12, 2017).

The Open University (2016), "Exploring equality and equity in education", available at: www. open.edu/openlearn/education/exploring-equality-and-equity-education/content-section-6 (accessed February 2, 2018).

Tomarkova, R. (2015), "A walk through the multimodal landscape of university websites", Brno Studies in English, Vol. 41 No. 1, pp. 77-100, available at: https://digilib.phil.muni.cz/ bitstream/handle/11222.digilib/134765/1_BrnoStudiesEnglish_41-2015-1_7.pdf?sequence=1 (accessed August 12, 2017).

United Nations Educational, Scientific, and Cultural Organization (2016), "UNESCO programme: From exclusion to empowerment", available at: http:/unesdoc.unesco.org/images/0024/002443/ 244355e.pdf (accessed February 2, 2017).

United Nations (n.d.), "Goal 4: ensure inclusive and quality education for all and promote lifelong learning", available at: www.un.org/sustainabledevelopment/education/ (accessed February 2, 2018). 
Weber, J.J. (2001), “A concordance- and genre-informed approach to ESP essay writing”, Genre analysis ELT Journal, Vol. 55 No. 1, pp. 14-20, available at: https://doi.org/10.1093/elt/55.1.14 (accessed August 12, 2017).

Xiao, Z. (n.d.), "Making statistical claims", available at: www.lancaster.ac.uk $\% 2 \mathrm{Ffass} \% 2 \mathrm{Fprojects} \%$ 2Fcorpus\%2FZJU\%2Fxpresentations \%2Fsession \% 25201.ppt\&usg=AFQjCNHrK-8YLAVHqQ -1D4vW-7O0HRAahg (accessed May 21, 2017).

Xiao, Z. and McEnery, A. (2005), "Two approaches to genre analysis", Journal of English Linguistics, Vol. 33 No. 1, pp. 62-82, available at: http:/journals.sagepub.com/doi/abs/10.1177/00754242042 73957 (accessed August 12, 2017).

Yang, W-h (2013), “Why choose us?' texts in university websites: a genre analysis”, Taiwan International ESP Journal, Vol. 5, pp. 45-80.

Yasmin, D. (2010), "Can open and distance education bring social justice to the weaker sections of the society: a case study on directorate of distance education, university of North Bengal, West Bengal, India”, Sixth Pan-Commonwealth Forum on Open Learning, Kochi, November 24-28, available at: http://oasis.col.org/bitstream/handle/11599/2178/2010_Yasmin_ODL_social_justice. pdf?sequence=1\&isAllowed=y (accessed February 10, 2018).

Yilmaz, E. and Soruc, A. (2015), "The use of concordance for teaching vocabulary: a data-driven learning approach", Procedia - Social and Behavioral Sciences, Vol. 191, pp. 2626-2630, available at: https://doi.org/10.1016/j.sbspro.2015.04.400 (accessed August 12, 2017).

Zhang, T. (2017), "The Marketization of higher education discourse: a genre analysis of university website homepages in China", Higher Education Studies, Vol. 7 No. 3, pp. 64-79, available at: https://doi.org/10.5539/hes.v7n3p64 (accessed August 20, 2017).

Zhang, Y. and O'Halloran, K.L. (2013), “Toward a global knowledge enterprise: University websites as portals to the ongoing marketization of higher education", Critical Discourse Analysis, Vol. 10 No. 4, pp. 468-485, available at: http://dx.doi.org/10.1080/17405904.2013.813777 (accessed August 12, 2017).

(The Appendix follows overleaf.) 
AAOUJ 13,1
Appendix

\begin{tabular}{|c|c|c|c|c|c|c|}
\hline \multirow{4}{*}{58} & Rank & \multicolumn{2}{|l|}{ Frequency } & \multirow{2}{*}{$\frac{\text { Keyness }}{2,819.79}$} & \multirow{2}{*}{$\begin{array}{r}\% \text { Diff } \\
2,481,077\end{array}$} & \multirow{2}{*}{$\begin{array}{l}\text { Keyword } \\
\text { Open }\end{array}$} \\
\hline & 9 & 409 & + & & & \\
\hline & 11 & 303 & + & $2,088.59$ & $1,838,034$ & International \\
\hline & 14 & 270 & + & $1,861.01$ & $1,637,841$ & Distance \\
\hline & 21 & 192 & + & $1,323.2$ & $1,164,658$ & Quality \\
\hline & 23 & 189 & + & $1,302.52$ & $1,146,459$ & System \\
\hline & 37 & 149 & + & $1,026.78$ & $903,800.8$ & Years \\
\hline & 39 & 148 & + & $1,019.89$ & $897,734.3$ & Time \\
\hline & 44 & 136 & + & 937.17 & $824,936.9$ & Established \\
\hline & 46 & 129 & + & 888.92 & $782,471.8$ & Cooperation \\
\hline & 54 & 110 & + & 757.97 & $667,209.3$ & National \\
\hline & 57 & 106 & + & 730.4 & $642,943.5$ & New \\
\hline & 59 & 102 & + & 702.84 & $618,677.7$ & Based \\
\hline & 74 & 88 & + & 606.35 & $533,747.4$ & Mutual \\
\hline & 79 & 85 & + & 585.68 & $515,548.1$ & Understanding \\
\hline & 94 & 79 & + & 544.33 & $479,149.4$ & Various \\
\hline & 105 & 73 & + & 502.98 & $442,750.7$ & Year \\
\hline & 113 & 68 & + & 468.53 & $412,418.5$ & Full \\
\hline & 120 & 66 & + & 454.75 & $400,285.6$ & Number \\
\hline & 123 & 65 & + & 447.86 & $394,219.1$ & Professional \\
\hline & 3 & 1267 & + & $8,748.68$ & $7,686,090$ & University \\
\hline & 4 & 780 & + & $5,381.19$ & $4,731,729$ & Education \\
\hline & 27 & 178 & + & $1,226.69$ & $1,079,728$ & School \\
\hline & 45 & 132 & + & 909.6 & 800,671.1 & Educational \\
\hline & 47 & 127 & + & 875.14 & $770,338.9$ & universities \\
\hline & 58 & 105 & + & 723.51 & 636,877 & Center \\
\hline & 60 & 101 & + & 695.94 & $612,611.3$ & College \\
\hline & 64 & 95 & + & 654.59 & $576,212.6$ & institutions \\
\hline & 89 & 80 & + & 551.22 & $485,215.8$ & Campus \\
\hline & 109 & 70 & + & 482.31 & $424,551.4$ & Centers \\
\hline & 111 & 69 & + & 475.42 & $418,484.9$ & Center \\
\hline & 125 & 64 & + & 440.97 & $388,152.7$ & Institute \\
\hline & 24 & 188 & + & $1,295.62$ & $1,140,392$ & Their \\
\hline & 77 & 171 & + & $1,166.21$ & 5,185,81.3 & Our \\
\hline & 76 & 86 & + & 592.57 & $521,614.5$ & His \\
\hline & 30 & 167 & + & $1,150.86$ & $1,012,997$ & Have \\
\hline & 36 & 302 & + & $2,068.34$ & 915,933.7 & Has \\
\hline & 38 & 297 & + & $2,033.89$ & $900,767.5$ & All \\
\hline & 48 & 124 & + & 854.46 & $752,139.6$ & First \\
\hline & 68 & 91 & + & 627.03 & $551,946.8$ & Signed \\
\hline & 71 & 90 & + & 620.14 & $545,880.3$ & More \\
\hline & 84 & 83 & + & 571.9 & $503,415.2$ & Well \\
\hline & 100 & 75 & + & 516.77 & $454,883.6$ & Ensure \\
\hline & 5 & 544 & + & $3,751.44$ & $3,300,048$ & Learning \\
\hline & 7 & 433 & + & $2,985.39$ & $2,626,672$ & Students \\
\hline & 15 & 239 & + & $1,647.25$ & $1,449,781$ & Programs \\
\hline & 16 & 236 & + & $1,626.56$ & $1,431,582$ & academic \\
\hline & 25 & 187 & + & $1,288.73$ & $1,134,326$ & Student \\
\hline & 26 & 179 & + & $1,233.58$ & $1,085,794$ & Study \\
\hline & 31 & 167 & + & $1,150.86$ & $1,012,997$ & Higher \\
\hline & 33 & 164 & + & $1,130.18$ & $994,797.5$ & Teaching \\
\hline Table AI. & 35 & 152 & + & $1,047.46$ & $922,000.1$ & Courses \\
\hline Top 100 Keywords & 49 & $\begin{array}{l}102 \\
123\end{array}$ & + & 847.57 & $746,073.1$ & Programs \\
\hline with positive keyness & 50 & 123 & + & 847.57 & $746,073.1$ & Support \\
\hline $\begin{array}{l}\text { in the "about Us" } \\
\text { sections of AAOU }\end{array}$ & & & & & & \\
\hline members' websites & & & & & & (continued) \\
\hline
\end{tabular}

Table AI.

Top 100 Keywords with positive keyness in the "about Us" sections of AAOU members' websites 


\begin{tabular}{|c|c|c|c|c|c|c|}
\hline Rank & Frequency & & Keyness & $\%$ Diff & Keyword & \\
\hline 56 & 106 & + & 730.4 & $642,943.5$ & Degree & \\
\hline 73 & 89 & + & 613.25 & $539,813.9$ & Faculty & \\
\hline 75 & 86 & + & 592.57 & $521,614.5$ & Course & \\
\hline 83 & 83 & + & 571.9 & $503,415.2$ & Studies & \\
\hline 87 & 82 & + & 565.01 & $497,348.7$ & Program & \\
\hline 101 & 75 & + & 516.77 & $454,883.6$ & Learners & 59 \\
\hline 110 & 70 & + & 482.31 & $424,551.4$ & Self & \\
\hline 114 & 68 & + & 468.53 & $412,418.5$ & Professor & \\
\hline 127 & 64 & + & 440.97 & $388,152.7$ & Prof & \\
\hline 128 & 63 & + & 434.07 & $382,086.2$ & Registration & \\
\hline 51 & 121 & + & 833.79 & $733,940.2$ & Provide & \\
\hline 85 & 82 & + & 565.01 & $497,348.7$ & Achieve & \\
\hline 88 & 81 & + & 558.11 & $491,282.3$ & Service & \\
\hline 98 & 76 & + & 523.66 & $460,950.1$ & Providing & \\
\hline 41 & 142 & + & 978.53 & $861,335.6$ & Financial & \\
\hline 69 & 90 & + & 620.14 & $545,880.3$ & Chancellor & \\
\hline 80 & 84 & + & 578.79 & $509,481.6$ & Division & \\
\hline 86 & 82 & + & 565.01 & $497,348.7$ & President & \\
\hline 90 & 80 & + & 551.22 & $485,215.8$ & Council & \\
\hline 96 & 77 & + & 530.55 & $467,016.5$ & Business & \\
\hline 97 & 76 & + & 523.66 & $460,950.1$ & Department & \\
\hline 103 & 73 & + & 502.98 & $442,750.7$ & memorandum & \\
\hline 112 & 69 & + & 475.42 & $418,484.9$ & Vice & \\
\hline 124 & 64 & + & 440.97 & $388,152.7$ & Control & \\
\hline 66 & 94 & + & 647.7 & $570,146.1$ & Training & \\
\hline 62 & 98 & + & 675.27 & $594,411.9$ & Online & \\
\hline 70 & 90 & + & 620.14 & $545,880.3$ & Face & \\
\hline 18 & 206 & + & $1,419.72$ & $1,249,588$ & Development & \\
\hline 19 & 203 & + & $1,399.04$ & $1,231,389$ & Management & \\
\hline 42 & 138 & + & 950.96 & $837,069.8$ & Technology & \\
\hline 63 & 97 & + & 668.38 & $588,345.5$ & Services & \\
\hline 72 & 90 & + & 620.14 & $545,880.3$ & Resources & \\
\hline 92 & 79 & + & 544.33 & $479,149.4$ & Activities & \\
\hline 122 & 65 & + & 447.86 & $394,219.1$ & Plan & \\
\hline 52 & 118 & + & 813.11 & $715,740.9$ & Knowledge & \\
\hline 61 & 101 & + & 695.94 & $612,611.3$ & Information & \\
\hline 40 & 146 & + & $1,006.1$ & $885,601.4$ & Research & \\
\hline 81 & 83 & + & 571.9 & $503,415.2$ & Society & \\
\hline 82 & 83 & + & 571.9 & $503,415.2$ & State & \\
\hline 93 & 79 & + & 544.33 & $479,149.4$ & Public & \\
\hline 95 & 78 & + & 537.44 & $473,082.9$ & Policy & \\
\hline 106 & 72 & + & 496.09 & $436,684.3$ & Country & \\
\hline 108 & 71 & + & 489.2 & $430,617.8$ & Social & \\
\hline 115 & 67 & + & 461.64 & 406,352 & World & \\
\hline 117 & 66 & + & 454.75 & $400,285.6$ & Asia & \\
\hline 118 & 66 & + & 454.75 & $400,285.6$ & General & \\
\hline 119 & 66 & + & 454.75 & $400,285.6$ & Government & Table AI. \\
\hline
\end{tabular}

Corresponding author

Louise S. Villanueva can be contacted at: 1svillanueva@up.edu.ph

For instructions on how to order reprints of this article, please visit our website:

www.emeraldgrouppublishing.com/licensing/reprints.htm

Or contact us for further details: permissions@emeraldinsight.com 